\title{
Un médico bien querido
}

Se me pierde en las luces de los días y en las sombras de las noches el momento de mi vida cuando por primera vez oí decir que, para hacer el mejor ejercicio de la medicina, es necesario hacer una buena mezcla de los conocimientos científicos y las capacidades artísticas. Un día y una hora que sí recuerdo fueron cuando uno de los grupos de mis alumnos me concedió el honor de invitarme a que les diera la última clase en su acto de graduación. En esa oportunidad se me ocurrió decirles, entre otras cosas, que la medicina es la ciencia precisa de la imprecisión, que necesita precisar más para poder ser más efectiva y que la letra ilegible de los doctores es la máscara con la cual cubren la ignorancia.

Han venido a mi presente las anteriores reflexiones al recibir un correo electrónico que me envió una colega, en el que me incluye un artículo que se refiere a la necesidad de entender la literatura biomédica, a propósito de los múltiples artículos que llegan por uno u otro medio, incluidas las páginas electrónicas, para ser consultados no solo por los profesionales del área del salud sino por el público en general. Por supuesto, como lo dice el autor del escrito que comento, hay temas de una alta complejidad y en un lenguaje que solamente está al alcance de los especialistas sobre la materia y me atrevo a pensar que el ciudadano común, por adicto que sea a consultar en la red o en otro medio, no le va a dedicar su tiempo a ese tipo de artículos, cuando hay información que está escrita en «cristiano» con la que puede satisfacer sus inquietudes.

Por supuesto que la información puede ser tergiversada por ignorancia o malintencionadamente y ahí es donde las cosas se pueden complicar. Con alguna frecuencia los medios masivos emiten informaciones médicas a medias, y sabemos de sobra lo peligrosa que es una verdad a medias. Pero me cuento entre los que creen que si el paciente tiene información precisa y suficiente de su padecimiento es más beneficioso que perjudicial. Un paciente que sabe que padece de una enfermedad terminal, por ejemplo, es un paciente que acepta de mejor manera las medidas paliativas de sus dolores y quebrantos. Ya quedaron atrás, hace mucho tiempo, las épocas en que con muchas reservas, este «secreto» solo se revelaba a algunos familiares.

El médico tratante tiene la obligación de informar ampliamente al paciente y a sus familiares si es del caso, echando mano del arte y de la ciencia, utilizando una terminología llana y suficiente, estableciendo un diálogo antes que el inveterado monólogo que han usado los médicos, para explicarle cuál es el posible diagnóstico o las maneras o exámenes con los que se puede llegar a precisarlo; el o los posibles tratamientos indicados, el pronóstico que del tratamiento elegido se desprende y aunque sea muy doloroso, las posibles secuelas y, además, debe suministrar la información adicional que el paciente desee. Cuando se procede de esta manera, antes de que se configure una amenaza, se construye una oportunidad para la cooperación.

Por supuesto que los aspectos científicos y técnicos básicos de la medicina los debe adquirir el médico en la universidad, y la solvencia en los avances científicos será tan amplia como su disciplina de estudio. Pero para hacer sólido su componente humanístico requiere un cultivo extracurricular muy cuidadoso de la personalidad, que desarrolle la capacidad de apreciar la naturaleza en cualesquiera de sus expresiones; necesita también el ejercicio permanente de la lectura para sumergirse en la literatura que amplía los horizontes de la inconmensurable experiencia humana, de acuerdo con las preferencias, sin que falte la de tinte social. Debe, además, adquirir el convencimiento de que todas las expresiones artísticas son manifestaciones humanas que regocijan el alma con los aromas de lo bello, y predisponen al espíritu para reconocer a cualquier ser humano como la obra más perfecta del universo. Poseyendo estas actitudes y aptitudes y ejercitando cotidianamente la vocación de servicio incondicional a las gentes, adobada esa vocación con una fuerte dosis de sencillez y de humildad, logrará mantener alejados de sus actos y de sus pensamientos los nefastos microbios de la prepotencia, la petulancia, la arrogancia 
y, en fin, estará dispuesto para hacer el ejercicio profesional con un inmenso amor, con la seguridad de que todo lo que se hace bajo este signo siempre sale bien. Con estos haberes y otros muchos más que se le van sumando con el trascurso de los años, se puede esperar que el médico haga el ejercicio más humano y lo suficientemente científico de la profesión.

Porque el componente artístico es el que hace más humana la medicina, en tanto que la ciencia y su hija la tecnología son las que la hace fría y distante, y en el sentir de la mayoría de los seres humanos y de manera especial cuando está minada su vitalidad, les gusta más estar y hasta morir en las manos de un médico bien querido aunque sea muy brutico, que bajo los distantes servicios que dispensan las frías eminencias científicas. Así se lo recuerdo a quienes fueron mis alumnos que se toman el trabajo de saludarme con afecto en una calle o en un lugar cualquiera de la ciudad.

José De los Ríos Osorio

Médico

Medellín, marzo de 2016 